\title{
Prediksi Perubahan Penggunaan Lahan Akibat Pembangunan Gerbang TOL Krian dan Driyorejo di Kecamatan Driyorejo, Kabupaten Gresik
}

\author{
Mohammad Akhid Yunanto dan Cahyono Susetyo \\ Departemen Perencanaan Wilayah dan Kota, Fakultas Arsitektur Desain dan Perencanaan, \\ Institut Teknologi Sepuluh Nopember (ITS) \\ e-mail: cahyono_s@urplan.its.ac.id
}

\begin{abstract}
Abstrak-Pembangunan infrastruktur, salah satunya infrastruktur transportasi, akan berpengaruh terhadap perkembangan lahan disekitarnya. Penelitian ini ditujukan untuk mengkaji kemungkinan perubahan guna lahan di sekitar Gerbang TOL Krian dan Driyorejo di Kecamatan Driyorejo, Kabupaten Gresik. Penelitian ini diharapkan dapat menjadi masukan untuk pemerintah Kabupaten Gresik dalam mengantisipasi perubahan penggunaan lahan yang tidak sesuai dengan peruntukannya sebagaimana yang terdapat pada rencana tata ruang. Penentuan potensi perubahan penggunaan lahan dilakukan pada model spasial perubahan penggunaan lahan yang keseluruhan meluputi dua teknik analisis. (1) Teknik analisis regresi logistik bertujuan untuk mengidentifikasi variabel penentu dan menghasilkan model matematis perubahan penggunaan lahan dan (2) teknik analisis spasial kogistik biner digunakan untuk melakukan pemodelan spasial perubahan penggunaan lahan di Kecamatan Driyorejo, Kabupaten Gresik. Tiap tahapan penelitian menghasilkan luaran yang saling berkaitan. Terdapat 8 variabel penentu perubahan penggunaan lahan yang dihasilkan dari teknik analisis regresi logistik. Tinggi rendahnya kemungkinan perubahan penggunaan lahan ditentukan oleh jarak dari variabel-variabel tersebut. Adapun model spasial harga lahan dihasilkan dari model matematis memiliki konstanta 0,319 . Variabel yang berpengaruh positif dalam model tersebut adalah gerbang tol, wilayah permukiman, rencana jalan, sarana peribadatan dan jaringan listrik. Variabel yang berpengaruh negatif adalah sarana pendidikan, jaringan air bersih, dan jaringan gas. Hasil perumusan model spasial perubahan penggunaan lahan menunjukan bahwa probabilitas perubahan lahan di Kecamatan Driyorejo sebesar 0,000000583805 hingga 0,988594. Sedangkan untuk lahan tidak terbangun, lahan pertanian yang berpotensi untuk berubah adalah sebesar 307,29 hektar dan lahan RTH yang berpotensi untuk berubah adalah sebesar 34,9 hektar.
\end{abstract}

Kata Kunci-Gerbang TOL Krian dan Driyorejo, Pemodelan Spasial, Perubahan Penggunaan Lahan.

\section{PENDAHULUAN}

$\mathbf{I}^{\mathrm{N}}$ NFRASTRUKTUR merupakan sistem fisik yang menyediakan transportasi, pengairan, drainase, bangunan gedung dan fasilitas publik lainnya, yang dibutuhkan untuk memenuhi kebutuhan dasar manusia baik kebutuhan sosial maupun kebutuhan ekonomi [1]. Infrastruktur sendiri dalam sebuah sistem menopang sistem sosial dan sistem ekonomi sekaligus menjadi penghubung dengan sistem lingkungan. Ketersediaan infrastruktur memberikan dampak terhadap sistem sosial dan sistem ekonomi yang ada di masyarakat. Oleh karena itu, infrastruktur perlu dipahami sebagai dasar dalam mengambil kebijakan. Ketersediaan infrastruktur memberikan dampak terhadap sistem sosial dan sistem ekonomi yang ada di masyarakat. Pembangunan infrastruktur dengan skala yang besar akan mempengaruhi penggunaan lahan kawasan di sekitarnya. Oleh karena itu, pembangunan infrastruktur perlu dipahami sebagai dasar-dasar dalam mengambil kebijakan [2].

Penggunaan lahan adalah segala campur tangan manusia dengan tujuan untuk mencukupi kebutuhan baik material maupun spiritual, ataupun kebutuhan kedua-duanya. Penggunaan lahan yang tidak mempertimbangkan keseimbangan ekologi, dapat dilihat dari lahan yang semula merupakan rawa-rawa, sawah, kawasan penampung air hujan, daerah resapan air hujan dan lainnya, yang diubah menjadi kawasan permukiman, pertokoan, industri dan lain sebagainya dengan tidak mempertimbangkan kemampuan lahannya [3].

Akibat dari tidak diantisipasinya perubahan penggunaan lahan dapat menyebabkan ketidakmampuan lahan itu sendiri. Sehingga diperlukan langkah-langkah yang tepat untuk mengantisipasi perubahan penggunaan lahan akibat dari adanya pembangunan infrastruktur.

Saat ini sedang dilakukan pembangunan Jalan TOL Trans Jawa yang nantinya akan menghubungkan kota-kota di Pulau Jawa. TOL Trans Jawa merupakan jalan bebas hambatan yang dibangun untuk menyambung jalan TOL yang sudah ada sebelumnya di Pulau Jawa. Panjang total pembangunan TOL Trans Jawa adalah 649,98 km yang dimulai dari Cikampek, Jawa Barat hingga Banyuwangi, Jawa Timur.

Kabupaten Gresik, Jawa Timur termasuk kedalam wilayah Pulau Jawa yang dilalui salah satu ruas Jalan TOL Trans Jawa, yakni ruas jalan yang menghubungkan Kota Surabaya dan Mojokerto dengan panjang 36,27 km. Adanya Jalan TOL 
ruas Surabaya-Mojokerto, tentu akan mempengaruhi wilayah disekitarnya. Dalam hal ini adalah pada kawasan disekitar pintu gerbang TOL karena merupakan akses masuk dan keluar jalan TOL. Salah satu pintu TOL yang terdapat pada ruas TOL Surabaya-Mojokerto adalah Gerbang TOL Krian dan Driyorejo yang terletak di Kecamatan Driyorejo, Kabupaten Gresik.

Berdasarkan data diatas, penggunaan lahan disekitar Gerbang TOL Krian dan Driyorejo berpotensi berubah. Perubahan yang terjadi tidak bisa dipastikan sesuai dengan rencana yang sudah ada saat ini. Sehingga perlu dilakukan penelitian untuk mengetahui arah perubahan lahan yang ada di Kecamatan Driyorejo, Kabupaten Gresik.

\section{TINJAUAN PUSTAKA}

\section{A. Keterkaitan Pembangunan Infrastruktur Transportasi dan Perubahan Penggunaan Lahan}

Pembangunan infrastruktur jalan memicu perkembangan guna lahan disekitarnya. Terdapat perbedaan antara pembangunan jalan TOL dan jalan arteri mengenai dampaknya dalam memacu perkembangan wilayah. Pelayanan akses ke lahan di sepanjang jalan TOL cenderung kurang, sehingga satu-satunya akses yang ada adalah pintu masuk (interchange). Prioritas jalan arteri adalah moblitas dan aksesibilitas. Jalan arteri melayani akses ke lahan di sepanjang jalan. Oleh karena itu, perkembangan guna lahan pada jalan arteri dapat terjadi di sepanjang jalan [4].

Berdasarkan perbedaan tersebut, dapat disimpulkan bahwa pada jalan TOL perkembangan penggunaan lahan hanya terjadi pada pintu masuk (interchange), sedangkan jalan arteri primer terjadi di sepanjang pinggir jalan.

\section{B. Tata Guna Lahan}

Lahan dapat diartikan sebagai land settlemen, yaitu suatu tempat atau daerah dimana penduduk berkumpul dan hidup bersama, dimana mereka dapat menggunakan lingkungan setempat untuk mempertahankan, melangsungkan dan mengembangkan hidupnya. Dengan demikian sangatlah jelas bahwa setiap makhuk hidup pasti membutuhkan lahan untuk tumbuh dan berkembang, berbagai aktifitas manusia didalam ruang bumi ini tidak lepas dari fungsi lahan yang berbedabeda [5]. Lahan juga dapat diartikan sebagai bagian daratan dari permukaan bumi sebagai suatu lingkungan fisik yang meliputi tanah beserta segenap faktor yang mempengaruhi penggunaannya seperti iklim, relief, aspek geologi, dan hidrologi yang terbentuk secara alami maupun akibat pengaruh manusia [6].

Penggunaan lahan yang dapat daiartikan sebagai perwujudan fisik obyek-obyek yang menutupi lahan dan terkait dengan kegitan manusia pada sebidang lahan [7]. Penggunaan lahan juga dapat diartikan sebagai bentuk penutupan permukaan lahan atau pemanfaatan lahan baik yang merupakan bentukan alami maupun buatan manusia [6].
Perubahan penggunaan lahan merupakan peralihan dari penggunaan lahan tertentu menjadi pengunaan lainnya. Proses penggunaan lahan yang dilakukan manusia dari waktu ke waktu terus mengalami perubahan seiring dengan perkembangan peradaban dan kebutuhan manusia. Semakin tinggi kebutuhan manusia akan semakin tinggi terhadap kebutuhan lahan. Perubahan lahan juga dapat diartikan sebagai perubahan penggunaan atau aktivitas terhadap suatu lahan yang berbeda dari aktivitas sebelumnya, baik untuk tujuan komersial maupun industri. Berbagai fenomena perubahan penggunaan lahan telah terjadi dari waktu ke waktu [7]. Perubahan penggunaan lahan yang terjadi sejalan dengan semakin meningkatnya pertambahan jumlah penduduk yang secara langsung berdampak pada kebutuhan terhadap lahan yang semakin meningkat [8].

\section{Metode Analisis Regresi Logistik untuk Memprediksi Perubahan Penggunaan Lahan}

Statistika merupakan salah satu cabang penegtahuan yang paling banyak mendapatkan perhatian dan dipelajari oleh ilmuan dari hamper semua bidang ilmu penegtahuan, terutama para peneliti yang dalam penelitiannya banyak menggunakan satistika sebagi dasar analisis maupun perancangannya [9]. Maka dapatlah dikatakan bahwa statistika mempunyai sumbangan yang penting dan besar terhadap kemajuan berbagai bidang ilmu pengetahuan. Statistika harus dan penting dipelajari oleh para peneliti.

Regresi logistik adalah sebuah pendekatan untuk membuat model prediksi seperti halnya regresi linear. Perbedaannya adalah pada regresi logistik, peneliti memprediksi variabel terikat yang berskala dikotomi. Skala dikotomi yang dimaksud adalah skala data nominal dengan dua kategori, misalnya: Ya dan Tidak, Baik dan Buruk atau Tinggi dan Rendah.

\section{METODE PENELITIAN}

\section{A. Pendekatan dan Jenis Penelitian}

Pendekatan yang digunakan dalam penelitian ini adalah pendekatan kuantitaif. Pendekatan kuantitatif adalah suatu pendekatan penelitian yang secara primer menggunakan paradigma postpositivist dalam mengembangkan ilmu pengetahuan, menggunakan strategi penelitian seperti eksperimen dan survei yang memerlukan data statistik.

Sedangkan jenis penelitian yang digunakan dalam penelitian ini berdasarkan pendekatan kuantitatif adalah penelitian dengan metode korelasional. Metode korelasional adalah suatu metode penelitian untuk mengetahui hubungan dan tingkat hubungan antara dua variabel atau lebih tanpa ada upaya untuk mempengaruhi variabel tersebut sehingga tidak terdapat manipulasi variabel. Penelitian korelasional merupakan salah satu bagian penelitian ex-post facto karena pada umumnya peneliti tidak memanipulasi keadaan variabel yang ada dan langsung mencari adanya suatu hubungan dan tingkat hubungan variabel yang dinyatakan dalam koefisien 
korelasi. Dalam penelitian ini, metode korelasional digunakan untuk merumuskan model matematis serta penentuan arah perubahan penggunaan lahan.

\section{B. Variabel Penelitian}

Variabel penelitian dihasilkan dari sintesis kajian pustaka yang didapatkan dari berbagai sumber baik peneliti maupun para ahli untuk kemudian diuji dalam tahap analisis data dengan metode tertentu. Variabel dalam penelitian ini bersifat spasial yang nantinya akan dilakukan prediksi perubahan penggunaan lahan.

Berikut adalah variabel yang digunakan untuk memprediksi perubahan penggunaan lahan di Kecamatan Driyorejo.

Tabel 1.

Variabel Penelitian

\begin{tabular}{|c|c|c|}
\hline No & Variabel & Definisi Operasional \\
\hline 1. & Gerbang Tol & Jarak titik sampel dari Gerbang TOL \\
\hline 2. & Wilayah Industri & Jarak titik sampel dari Wilayah Industri \\
\hline 3. & Wilayah Permukiman & $\begin{array}{l}\text { Jarak titik sampel dari Wilayah } \\
\text { Permukiman }\end{array}$ \\
\hline 4. & Rencana Jalan & Jarak titik sampel dari Rencana Jalan \\
\hline 5. & Pusat Perdagangan dan & Jarak titik sampel dari Pusat \\
\hline 6 & $\begin{array}{l}\text { Jasa } \\
\text { Sarana Pendidikan }\end{array}$ & $\begin{array}{l}\text { Perdagangan dan Jasa } \\
\text { Jarak titik sampel dari Sarana Pendidikan }\end{array}$ \\
\hline 7. & Sarana Kesehatam & Jarak titik sampel dari Sarana Kesehatan \\
\hline 8. & Sarana Peribadatan & $\begin{array}{l}\text { Jarak titik sampel dari Sarana } \\
\text { Peribadatan }\end{array}$ \\
\hline 9. & Sarana Perkantoran & $\begin{array}{l}\text { Jarak titik sampel dari Sarana } \\
\text { Perkantoran }\end{array}$ \\
\hline 10. & Jaringan Listrik & Jarak titik sampel dari Jaringan Listrik \\
\hline 11. & $\begin{array}{l}\text { Jaringan } \\
\text { Telekomunikasi }\end{array}$ & $\begin{array}{l}\text { Jarak titik sampel dari Jaringan } \\
\text { Telekomunikasi }\end{array}$ \\
\hline 12. & Jaringan Air Bersih & $\begin{array}{l}\text { Jarak titik sampel dari Jaringan Air } \\
\text { Bersih }\end{array}$ \\
\hline 13. & Jaringan Gas & Jarak titik sampel dari Jaringan Gas \\
\hline
\end{tabular}

\section{Populasi dan Sampel}

Populasi yang digunakan dalam penelitian ini adalah seluruh wilayah Kecamatan Driyorejo, Kabupaten Gresik. Dalam hal ini beserta dengan seluruh variabel yang berada didalam wilayah Kecamatan Driyorejo, Kabupaten Gresik.

Sampel yang digunakan dalam penelitian ini adalah titiktitik sampel yang dipilih secara acak sejumlah 100 titik dengan menggunakan tools Create Random Point pada software ArcGIS. Tools tersebut menghasilkan titik sampel secara acak di Kecamatan Driyorejo, Kabupaten Gresik. Jumlah titik sampel sebanyak 100 titik ditetapkan karena dirasa telah cukup mewakili seluruh wilayah penelitian.

Titik sampel yang telah ditetapkan akan diklasifikasikan mana yang telah mengalami perubahan penggunaan lahan dan mana yang tidak mengalami perubahan penggunaan lahan. Jumlah titik sampel setiap klasifikasi ditetapkan dengan komposisi $50 \%$ pada lahan yang penggunaan lahannya telah berubah mulai dari Tahun 2010 hingga 2018 dan 50\% pada lahan yang penggunaan lahannya tetap.

\section{Metode Pengumpulan Data}

Metode pengumpulan data yang digunakan dalam penelitian ini dibagi menjadi dua, yakni pengumpulan data primer dan pengumpulan data sekunder. Teknik pengumpulan data primer yang digunakan pada penelitian ini adalah observasi lapangan. Observasi merupakan pengamatan langsung dengan menggunakan mata tanpa ada pertolongan alat standar lain untuk keperluan tertentu. Pengamatan langsung dilakukan secara terstruktur yaitu subyek atau peneliti telah mengetahui aspek apa dari aktivitas yang diamatinya, sesuai dengan masalah serta tujuan penelitian yang telah ditetapkan. Dalam penelitian ini observasi dilakukan untuk mengetahui kondisi eksisiting fisik dan lingkungan wilayah.

Pengumpulan data sekunder dilakukan dengan studi literatur. Data sekunder yang dibutuhkan dalam penelitian ini berhubungan dengan karakteristik perubahan penggunaan lahan. Dalam penelitian ini, studi literatur dilakukan untuk mencapai semua sasaran. Beberapa dokumen yang dijadikan literatur dalam penelitian ini antara lain rencana atau dokumen tata ruang terkait perubahan penggunaan lahan di Kecamatan Driyorejo, Kabupaten Gresik (RTRW Kabupaten Gresik), hasil penelitian sejenis, buku-buku, serta beberapa Tugas Akhir dan Thesis.

\section{E. Metode Analisis Data}

Metode penelitian yang digunakan menggunakan teknik analisis kuantitatif. Teknik analisis kuantitatif digunakan untuk mengetahui variabel penentu perubahan penggunaan lahan dan juga digunakan dalam perumusan persamaan regresi logistik dan arah perubahan penggunaan lahan. Adapun metode analisis yang digunakan untuk mencapai sasaran dan tujuan penelitian ini dijelaskan pada gambar di bawah ini. 


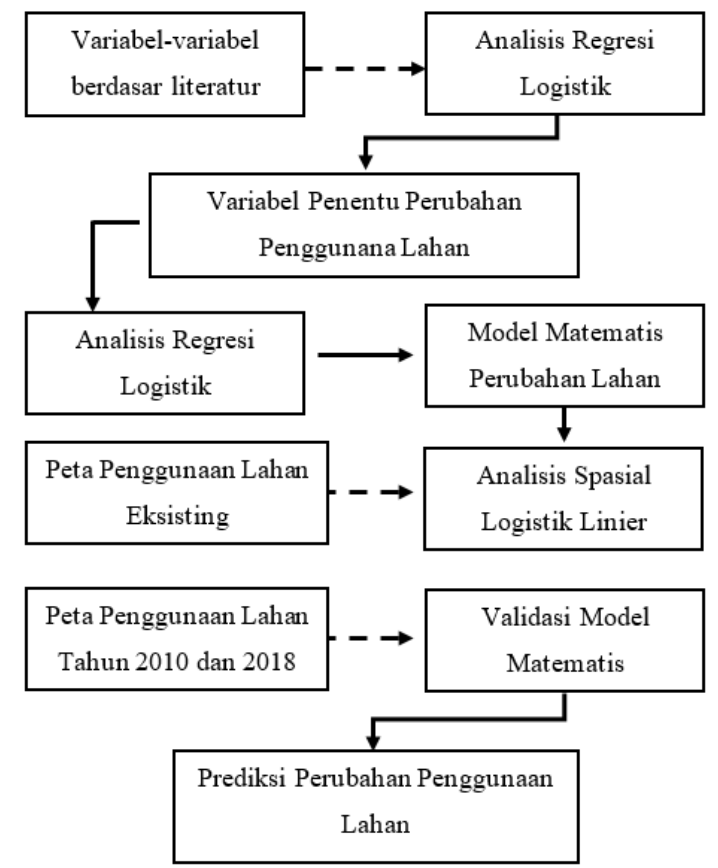

Gambar 1. Metode Analisis Prediksi Perubahan Penggunaan Lahan di Kecamatan Driyorejo, Kabupaten Gresik.

Dari gambar diatas dapat dilihat bahwa analisis yang digunakan adalah analisis regresi logistik dan analisis spasial logistik linier. Analisis regresi logistik digunakan untuk mencari variabel penentu perubahan penggunaan lahan dan merumuskan model matematis perubahan penggunaan lahan.

Sebelum dilakukan analisis regresi logistik, perlu dilakukan perhitungan jarak antara titik sampel yang telah ditetapkan dengan variabel. Teknik pengukuran jarak yang digunakan adalah dengan menggunakan tools Euclidean Distance pada software ArcMap. Adapun ukuran untuk satu cell yang digunakan dalam penelitian ini adalah $1 \mathrm{x} 1$ meter yang dapat menunjukkan tingkat kedetailan cell cukup tinggi. Jarak euklides tersebut kemudian dimasukkan ke dalam titik sampel harga lahan dengan tools Extract Multi Values to Point. Hasilnya akan muncul kolom atau field baru pada tiap titik sampel harga lahan yang memuat nilai-nilai jarak pada tiap variabel penentu harga lahan.

Langkah selanjutnya adalah melakukan analisis regresi logistik untuk menentukan variabel penentu perubahan penggunaan lahan. Dalam penelitian ini, variabel dependent yang digunakan adalah perubahan penggunaan lahan. Dalam regresi logistik, persamaan regresi akan menghubungkan logit dari perubahan (pi) yang berfungsi sebagai variabel respon dengan sejumlah variabel prediktor $\mathrm{Xi}(1,2, \ldots \mathrm{k})$. Persamaan regresi logistik dapat dituliskan sebagai berikut:

$$
p i=\frac{\exp a+\beta 1 X i+\beta 2 X 2 \_\beta k X k}{1+\exp \cdot a+\beta 1 X 1+\beta 2 X 2+\beta k X k},
$$

Dimana, pi adalah probabilitas terjadinya peristiwa i, $\alpha$ adalah konstanta persamaan regresi linier, $\beta 1$ adalah koefisien dari variabel prediktor ke 1 , dan Xk adalah variabel prediktor $(1,2, \ldots \mathrm{k})$. Sedangkan analisis regresi logistik yang dilakukan adalah dengan menggunakan software SPSS. SPSS dipilih karena dalam prosesnya dapat dilakukan dengan cukup mudah dan tidak memerlukan waktu yang lama. Pada SPSS, tools yang digunakan adalah Logistic Regression. Dalam menentukan variabel penentu perubahan penggunaan lahan perlu diperhatikan kolom Sig pada Tabel Variabilities in The Equation. Kolom tersebut menunjukan tingkat pengaruh masing-masing variabel terhadap perubahan penggunaan lahan di Kecamatan Driyorejo. Variabel yang memiliki nilai sig kurang dari 0,05 dianggap tidak mempengaruhi perubahan penggunaan lahan, oleh karena itu dapat dihilangkan pada proses analisis selanjutnya.

Setelah ditetapkan variabel penentu perubahan penggunaan lahan di Kecamatan Driyorejo, Kabupaten Gresik, selanjutnya dilakukan perumusan model matematis perubahan penggunaan lahan. Untuk memperoleh pemodelan perubahan penggunaan lahan di Kecamatan Driyorejo, Kabupaten Gresik kembali digunakan analisis dengan menggunakan analisis regresi logistik. Berbeda dengan analisis regresi logistik sebelumnya, pada analisis kedua ini variabel penentu perubahan penggunaan lahan yang menjadi masukan adalah variabel yang memiliki nilai pengaruh lebih dari 0,05 . Sedangkan untuk proses analisisnya sendiri masih sama hingga didapatkan hasil Tabel Variabilities in The Equation.

Jika pada analisis pertama kolom yang diperhatikan adalah kolom Sig, maka pada analisis ini kolom yang diperhatikan adalah kolom $B$. Kolom tersebut berisi nilai koefisien setiap variabel yang dapat digunakan sebagai persamaan regresi logistik. Selanjutnya nilai-nilai tersebut akan dijadikan model matematis perubahan penggunaan lahan.

Selanjutnya dilakukan analsis spasial logistik linier untuk mengetahui arah perubahan penggunaan lahan. Masukan yang digunakan dalam memprediksi arah perubahan penggunaan lahan adalah model matematis perubahan penggunaan lahan. Model matematis tersebut diolah dengan cara me-running menggunakan tools Raster Calculator pada software ArcMap maka akan dihasilkan model spasial perubahan penggunaan lahan berbentuk raster.

\section{HASIL DAN PEMBAHASAN}

\section{A. Perhitungan Jarak dengan Euclidean Distance}

Penggunaan Euclidean Distance bertujuan untuk menghitung jarak suatu objek dalam format raster atau vektor (feature) yang dinyatakan dalam ukuran cell. Hasil dari analisis berupa peta jarak euklides berformat raster. Dalam penelitian ini, ukuran cell yang digunakan sebagai luaran adalah $1 \times 1$, karena angka tersebut dinilai cukup detail.

Variabel yang digunakan dalam penelitian ini adalah variabel spasial yang menunjukkan nilai lokasi suatu lahan. Variabel-variabel tersebut menentukan suatu lahan menjadi strategis atau tidak, sehingga berkaitan dengan jarak atau kedekatan lahan terhadap variabel-variabel tersebut dan nilai jarak suatu titik dinyatakan dengan satuan meter terhadap 
variabel yang terdekat dengan titik tersebut. Berikut data peta 13 variabel independen dalam bentuk jarak spasial.

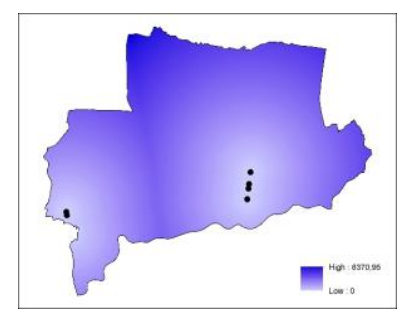

Gambar 2. Jarak dari variabel gerbang TOL.

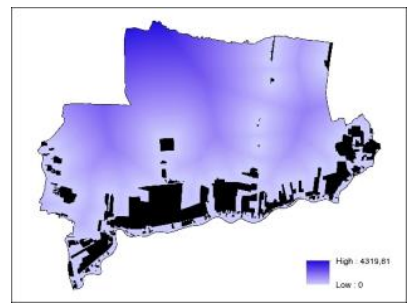

Gambar 3. Jarak dari variabel wilayah industri.

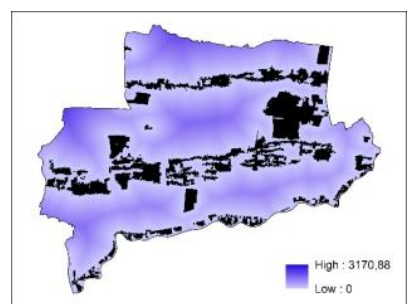

Gambar 4. Jarak dari variabel wilayah permukiman.

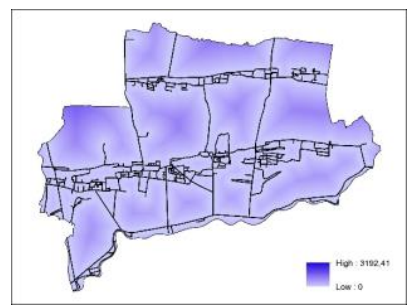

Gambar 5. Jarak dari variabel rencana jalan.

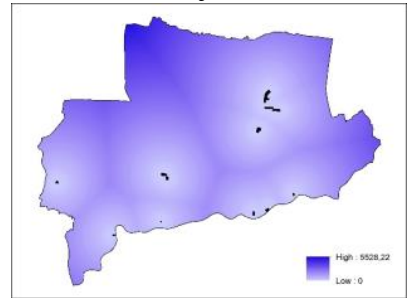

Gambar 6. Jarak dari variabel pusat perdagangan dan jasa.

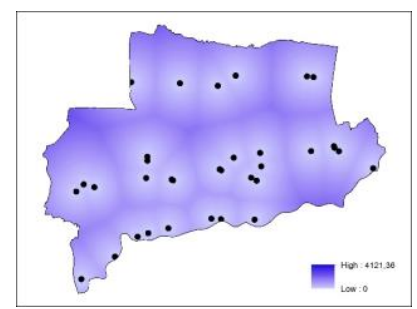

Gambar 7. Jarak dari variabel sarana pendidikan.

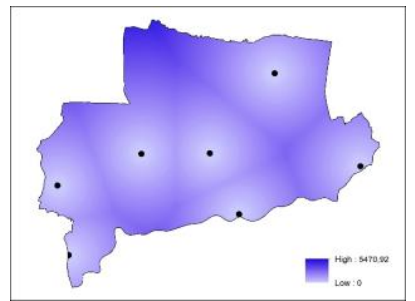

Gambar 8. Jarak dari variabel sarana kesehatan.

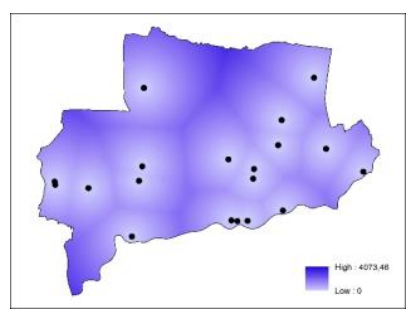

Gambar 9. Jarak dari variabel sarana perkantoran.

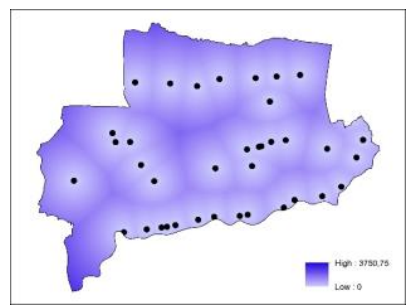

Gambar 10. Jarak dari sarana peribadatan.

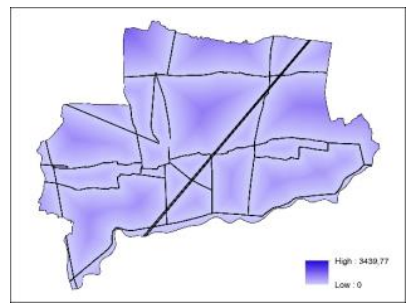

Gambar 11. Jarak dari jaringan listrik.

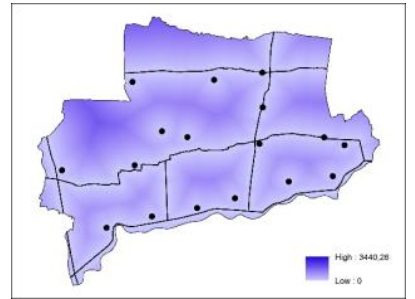

Gambar 12. Jarak dari jaringan telekomunikasi.

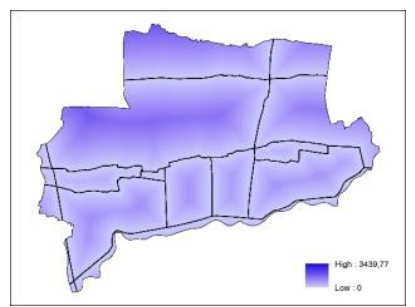

Gambar 13. Jarak dari jaringan air bersih.

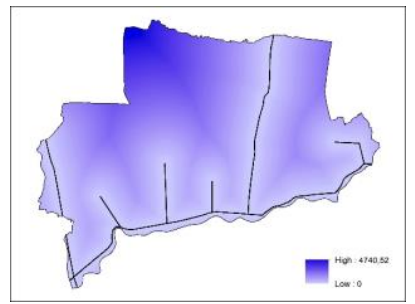

Gambar 14. Jarak dari jaringan gas. 
Setelah dilakukan proses Euclidean Distance, selanjutnya perlu dilakukan input data jarak terhadap titik sampel yang telah ditentukan. Proses ini dilakukan bertujuan untuk mengubah data spasial menjadi tabulasi, sehingga dapat dilakukan analisis regresi logistik. Tools yang digunakan adalah Extract Multi Values to Point pada Software EZRI ArcMap 10.1. Data yang menjadi input adalah jarak titik sampel terhadap 13 variabel yang telah dibuat peta Euclidean Distancenya. Data jarak tersebut kemudian akan menjadi kolom baru pada tabel atribut. Pada kolom terakhir ditambahkan lagi kolom yang menunjukkan lokasi titik sampel tersebut, apabila titik sampel berada pada lahan yang berubah penggunaan lahannya, maka nilai $\mathrm{Y}$ nya adalah 1 . Sebaliknya, apabila titik sampel berada pada lahan yang penggunaannya tetap, maka nilai Y nya adalah 0 .

\section{B. Seleksi Variabel dengan Analisis Regresi Logistik}

Tabel 2.

Variables in the Ecuationnstant (1)

\begin{tabular}{|c|c|c|c|c|c|c|c|c|c|}
\hline \multirow{2}{*}{\multicolumn{2}{|c|}{\begin{tabular}{|l|} 
\\
Step $1^{a} \quad \times 1$
\end{tabular}}} & \multirow[b]{2}{*}{$\begin{array}{l}801 \\
.001\end{array}$} & \multirow{2}{*}{$\frac{\text { SE. }}{.000}$} & \multirow[b]{2}{*}{$\begin{array}{l}\text { wald } \\
1.081\end{array}$} & \multirow[b]{2}{*}{1} & \multirow[b]{2}{*}{$\frac{519}{298}$} & \multirow[b]{2}{*}{$\frac{E x p(B)}{1.001}$} & \multicolumn{2}{|c|}{$95 \%$ C. fror EXP(B) } \\
\hline & & & & & & & & $\frac{\text { Lower }}{1.000}$ & $\frac{\text { Upper }}{1.001}$ \\
\hline & $x_{2}$ & .008 & .003 & 8.788 & 1 & .003 & .992 & .987 & .997 \\
\hline & & .004 & .002 & 2.871 & 1 & 102 & 1.0.04 & $\begin{array}{l}.9999 \\
.9990\end{array}$ & $\begin{array}{l}1.008 \\
\end{array}$ \\
\hline & & & .001 & & & .697 & 1.000 & & \\
\hline & $\times 6$ & .004 & .002 & 3.404 & 1 & .065 & .996 & .992 & 1000 \\
\hline & $\times 7$ & .003 & .001 & 8.533 & 1 & .003 & 1.003 & 1.001 & 1.005 \\
\hline & 88 & .000 & 002 & & 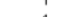 & 173 & 999 & & 1.004 \\
\hline & $\times 10$ & 003 & 015 & 049 & 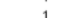 & 890 & 1003 & 974 & 1.002 \\
\hline & $x+1$ & 16 & .003 & 4.058 & 1 & .044 & 1.006 & 1.000 & 1.01 \\
\hline & $\times 12$ & .004 & .015 & .069 & 1 & .793 & .996 & .967 & 1.026 \\
\hline & $\begin{array}{l}x_{13} \\
\text { constant }\end{array}$ & $\begin{array}{r}.000 \\
3.010\end{array}$ & 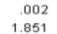 & $\begin{array}{l}.015 \\
.264\end{array}$ & $\frac{1}{1}$ & 1.903 & $\begin{array}{l}1.000 \\
.049\end{array}$ & 996 & 1.004 \\
\hline
\end{tabular}

Setelah didapatkan jarak titik sampel terhadap variabel, selanjutnya dapat dilakukan seleksi variabel pengaruh perubahan penggunaan lahan dengan menggunakan analisis regresi logistik. Analisis dilakukan dengan bantuan software SPSS. Hasil dari analisis regresi logistik tersebut adalah tabel Variables in the Equation. Pada tabel tersebut perlu diperhatikan kolom Sig yang menunjukan tingkat pengaruh variabel. Karena pada analisis tersebut nilai alpha yang digunakan adalah 5\%, maka variabel yang dianggap mempengaruhi perubahan penggunaan lahan di Kecamatan Driyorejo adalah yang memiliki nilai Sig lebih dari 0,05. Tabel 2 merupakan Variables in the Equation hasil analisis regresi logistik.

Dari tabel diatas dapat dilihat bahwa variabel yang memiliki nilai siknifikansi dibawah 0,05 adalah variabel X2, $\mathrm{X} 7$, dan X11. X2 adalah variabel wilayah industri, X7 adalah variabel sarana kesehatan, dan X11 adalah variabel sarana kesehatan. Variabel-variabel tersebut tidak dianggap tidak mempengaruhi perubahan penggunaan lahan di Kecamatan Driyorejo, Kabupaten Gresik. Sehingga 3 variabel tersebut dapat dihilangkan pada analisis berikutnya.

\section{Perumusan Model Matematis Perubahan Penggunaan} Lahan

Perumusan model matematis kembali dilakukan dengan menggunakan analisis regresi logistik. Analisis dilakukan dengan bantuan software SPSS. Namun yang membedakan analisis perumusan model matematis ini dengan seleksi variabel sebelumnya adalah variabel independennya. Jika pada analisis seleksi variabel sebelumnya menggunakan seluruh variabel, pada analisis perumusan model matematis ini variavel yang digunakan adalah 10 variabel yang dianggap mempengaruhi perubahan penggunaan lahan yang telah didapatkan pada analisis sebelumnya.

Tabel 3 .

Variables in the Ecuationnstant (1)

\begin{tabular}{|c|c|c|c|c|c|c|c|c|c|}
\hline & \multirow[b]{2}{*}{ B } & \multirow[b]{2}{*}{ S.E. } & \multirow[b]{2}{*}{ Wald } & \multirow[b]{2}{*}{ df } & \multirow[b]{2}{*}{ Siq. } & \multirow[b]{2}{*}{$\operatorname{Exp}(B)$} & \multicolumn{2}{|c|}{$95 \%$ C.l.for EXP(B) } \\
\hline & & & & & & & & Lower & Upper \\
\hline \multirow{11}{*}{ Step $1^{d a}$} & $x_{1}$ & .001 & .000 & 8.199 & 1 & .004 & 1.001 & 1.000 & 1.002 \\
\hline & $x_{3}$ & .002 & .001 & 1.775 & 1 & .183 & 1.002 & .999 & 1.005 \\
\hline & $x_{4}$ & .003 & .003 & .959 & 1 & .327 & 1.003 & .997 & 1.008 \\
\hline & $\times 5$ & .000 & .001 & .655 & 1 & .418 & .999 & .998 & 1.001 \\
\hline & $\times 6$ & .003 & .001 & 5.203 & 1 & .023 & .997 & .994 & 1.000 \\
\hline & $x_{8}$ & .001 & .002 & .486 & 1 & .486 & 1.001 & .998 & 1.004 \\
\hline & $x_{9}$ & .000 & .001 & 1.409 & 1 & .235 & .999 & .998 & 1.001 \\
\hline & $\times 10$ & .007 & .005 & 2.123 & 1 & .145 & 1.007 & .997 & 1.017 \\
\hline & $\times 12$ & .006 & .006 & 1.127 & 1 & .289 & .994 & .983 & 1.005 \\
\hline & $\times 13$ & .003 & .001 & 5.601 & 1 & .018 & .997 & .995 & 1.000 \\
\hline & Constant & .319 & .977 & .107 & 1 & .744 & 1.376 & & \\
\hline
\end{tabular}

Hasil dari analisis regresi logistik tersebut adalah tabel Variables in the Equation. Pada tabel tersebut perlu diperhatikan kolom $B$ yang menunjukan nilai koefisien masing-masing variabel. Nantinya, koefisien tersebut digunakan untuk merumuskan sebuah persamaan regresi logistik. Dari persamaan regresi logistik itulah dapat dihasilkan model matematis perubahan penggunaan lahan. Tabel 3 merupakan Variables in the Equation hasil analisis regresi logistik.

Dari tabel diatas dapat dilihat nilai koefisien masingmasing variabel. Terdapat 1 variabel yang nilai koefisiennya 0 , sehingga variabel-variabel tersebut tidak perlu dimasukkan kedalam model matematis perubahan penggunaan lahan. Variabel tersebut adalah X5 dan X9. X5 adalah variabel Perdagangan dan Jasa dan $\mathrm{X} 9$ adalah variabel Sarana Perkantoran.

Sehingga dapat dituliskan model matematis perubahan penggunaan lahan adalah sebagai berikut.

$\mathrm{PI}=\left(\operatorname{EXP}\left(0,319+0,001 \mathrm{X}_{1}+0,002 \mathrm{X}_{3}+0,003 \mathrm{X}_{4}-\right.\right.$ $0.003 \mathrm{X}_{6}+0.001 \mathrm{X}_{8}+0.007 \mathrm{X}_{10}-0.006 \mathrm{X}_{12}-$ $\left.\left.0.003 \mathrm{X}_{13}\right)\right) /\left(1+\operatorname{EXP}\left(0,319+0,001 \mathrm{X}_{1}+0,002 \mathrm{X}_{3}+\right.\right.$ $0,003 \mathrm{X}_{4}-0.003 \mathrm{X}_{6}+0.001 \mathrm{X}_{8}+0.007 \mathrm{X}_{10}-0.006 \mathrm{X}_{12}-$

\section{Perumusan Model Spasial Perubahan Penggunaan Lahan}

Model matematis yang telah dihasilkan pada analisis regresi logistik selanjutnya dispasialkan menggunakan tools Raster Calculator pada software ESRI ArcGIS 10.1. Model spasial tersebut menunjukkan probabilitas perubahan penggunaan lahan. Data spasial perubahan penggunaan lahan berbasis pada titik, sehingga setiap titik memiliki nilai yang berbeda.

Hasil dari analisis menggunakan tools Raster Calculator adalah peta model spasial perubahan penggunaan lahan. Model spasial ini berbasis titik setiap titik memiliki nilai mulai 0 hingga 1 . Nilai ini menunjukkan probabilitas perubahan penggunaan lahan. Berikut adalah Peta Model 
Matematis Perubahan Penggunaan Lahan di Kecamatan Driyorejo, Kabupaten Gresik.

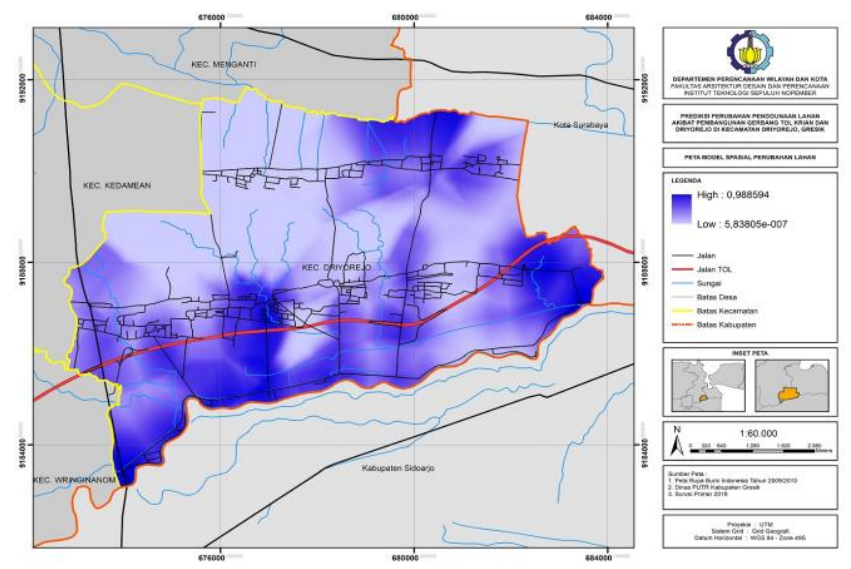

Gambar 15. Peta Model spasial perubahan penggunaan lahan.

Hasil perumusan model spasial perubahan penggunaan lahan di Kecamatan Driyorejo menunjukan bahwa probabilitas perubahan lahan di Kecamatan Driyorejo sebesar 0,000000583805 hingga 0,988594 . Nilai tersebut dapat diartikan apabila semakin besar, maka kemungkinan untuk lahan tersebut berubah juga semakin besar.

\section{E. Penyusunan Data Perubahan Penggunaan Lahan}

Batas kelas perubahan penggunaan lahan dibagi menjadi 2, yakni lahan yang berpotensi untuk berubah dan lahan yang berpotensi untuk tidak berubah. Standar yang digunakan adalah $75 \%$, dimana maka wilayah yang memiliki nilai probabilitas dibawah 0,75 yang berarti wilayah tersebut berpotensi untuk tidak berubah dan diberikan nilai 0 . Sebaliknya, wilayah yang memiliki nilai probabilitas lebih dari 0,75 yang berarti wilayah tersebut berpotensi untuk berubah dan diberikan nilai 1. Selanjutnya dilakukan Reclassify pada ESRI ArcGGIS 10.1 untuk menampilkan data spasial harga lahan menurut kelasnya.

Selanjutnya data yang ada dikonversi. Konversi data dari raster ke vektor dalam bentuk shapefile dibutuhkan untuk tahapan berikutnya, yaitu penyusunan data baru. Konversi data spasial menggunakan Conversion Tools di dalam sub menu From Raster kemudian pada bagian Raster to Polygon. Hasil dari perhitungan luas adalah luas wilayah yang berpotensi untuk berubah adalah 882,68 Hektar. Sedangkan luas wilayah yang berpotensi untuk tidak berubah adalah 4.590,19 Hektar.
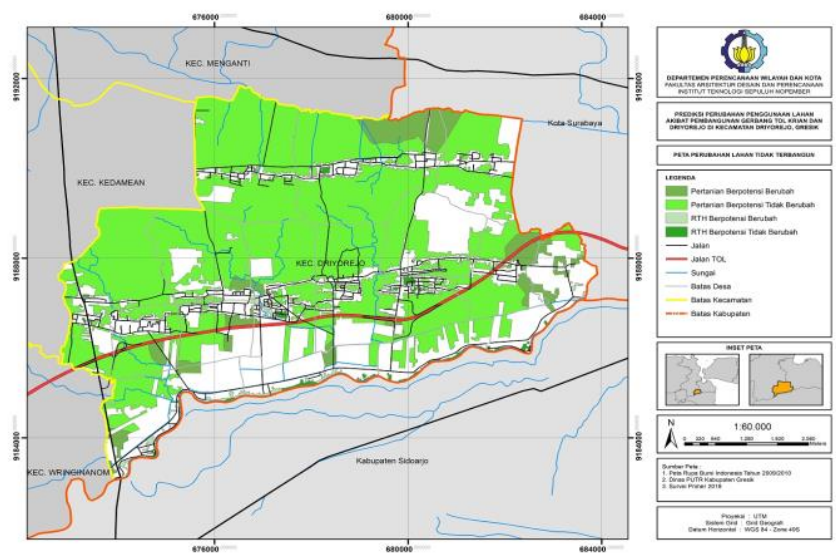

Gambar 16. Peta potensi perubahan penggunaan lahan pada lahan tidak terbangun.

Selanjutnya dilakukan penyusunan data yang merupakan tahap akhir dalam prediksi perubahan penggunaan lahan. Output akhir dari tahap ini yaitu peta potensi perubahan penggunaan lahan. Langkah pertama yaitu melakukan tumpang tindih data spasial potensi perubahan penggunaan lahan dan penggunaan lahan eksisting Kecamatan Driyorejo tahun 2018 menggunakan Overlay Intersect pada ESRI ArcGIS 10.1. Kemudian menyediakan kolom (field) potensi perubahan penggunaan lahan pada Attribute Table yang dimiliki file baru hasil Overlay Intersect.

Hasil dari analisis ini terdapat 2 lahan tidak terbangun yang berpotensi untuk berubah yakni lahan pertanian dan RTH. Lahan pertanian yang berpotensi untuk berubah adalah seluas 307,29 Hektar. Sedangkan lahan RTH yang berpotensi untuk berubah adalah seluas 34,9 Hektar. Berikut adalah peta potensi perubahan penggunaan lahan pada lahan tidak terbangun di Kecamatan Driyorejo.

\section{KESIMPULAN}

Terdapat beberapa poin kesimpulan yang dihasilkan antara lain: (1) terdapat 8 variabel yang menentukan perubahan penggunaan lahan di Kecamtan Driyorejo, Kabupaten Gresik. Variabel-variabel tersebut adalah gerbang TOL, wilayah permukiman, rencana jalan, sarana pendidikan, sarana peribadatan, jaringan listrik, jaringan air bersih, dan jaringan gas, (2) model matematis perubahan penggunaan lahan berbentuk persamaan $\mathrm{Pi}=\left(\operatorname{Exp}\left(0,319+0,001 \mathrm{X}_{1}+0,002 \mathrm{X}_{3}+\right.\right.$ $0,003 \mathrm{X}_{4}-0.003 \mathrm{X}_{6}+0.001 \mathrm{X}_{8}+0.007 \mathrm{X}_{10}-0.006 \mathrm{X}_{12}-$ $\left.\left.0.003 \mathrm{X}_{13}\right)\right) /\left(1+\operatorname{Exp}\left(0,319+0,001 \mathrm{X}_{1}+0,002 \mathrm{X}_{3}+0,003 \mathrm{X}_{4}-\right.\right.$ $\left.0.003 \mathrm{X}_{6}+0.001 \mathrm{X}_{8}+0.007 \mathrm{X}_{10}-0.006 \mathrm{X}_{12}-0.003 \mathrm{X}_{13}\right) . \mathrm{Pi}$ merupakan probabilitas perubahan penggunaan lahan dan $\mathrm{X}$ adalah variabel-variabel yang mempenrgaruhi perubahan penggunaan lahan, dimana $X_{1}$ adalah gerbang TOL, $X_{3}$ adalah rencana wilayah permukiman, $\mathrm{X}_{4}$ adalah rencana jalan, $\mathrm{X}_{6}$ adalah sarana pendidikan, $\mathrm{X}_{8}$ adalah sarana peribadatan, $X_{10}$ adalah jaringan listrik, $X_{12}$ adalah jaringan air bersih, dan $\mathrm{X}_{13}$ adalah jaringan gas. (3) hasil perumusan model spasial perubahan penggunaan lahan menunjukan 
bahwa probabilitas perubahan lahan di Kecamatan Driyorejo sebesar 0,000000583805 hingga 0,988594. Sedangkan untuk lahan tidak terbangun, lahan pertanian yang berpotensi untuk berubah adalah sebesar 307,29 hektar dan lahan RTH yang berpotensi untuk berubah adalah sebesar 34,9 hektar.

\section{DAFTAR PUSTAKA}

[1] N. Grigg, Infrastructure Engineering and Management. John Wiley \& Sons, 1988.

[2] R. Kodoatie, Pengantar Manajemen Infrastruktur. Yogyakarta: Pustaka Pelajar, 2005.

[3] S. Ritohardoyo, Bahan Kuliah Penggunaan dan Tata Guna Lahan.
Yogyakarta: Fakultas Geografi UGM, 2002.

[4] N. Yuliastuti, "Analisis Kecenderungan Perubahan Penggunaan Lahan di Kawasan Jalan Arteri Semarang," Semarang, 1996.

[5] Bintarto, Pengantar Geografi Kota. Yogyakarta: Gadjah Mada University Press, 1977.

[6] Pemerintahan Republik Indonesia, "Undang-Undang No 41 Tahun 2009. Tentang Perlindungan Lahan Pertanian Pangan Berkelanjutan," 2009.

[7] K. Munibah, "Model Spasial Perubahan Penggunaan Lahan dan Arahan Penggunaan Lahan Berwawasan Lingkungan,” IPB, 2008.

[8] Kusrini., "Perubahan Penggunaan Lahan dan Faktor yang Mempengaruhinya di Kecamatan Gunungpati, Kota Semarang," Fakultas Geografi UGM, 2011.

[9] S. Ratno and Mustadjab, Analisis Regresi. Yogyakarta, 1992. 